\title{
Interrogating Western Modernity: Postcolonial Reflections on Occidental Claims and Action
}

\author{
Ina Kerner* \\ kerner@uni-koblenz.de \\ (University of Koblenz-Landau, Campus Koblenz, Germany)
}

\begin{abstract}
This paper deals with the way in which European modernity, and the West more generally, are reflected upon in the field of post- and decolonial theories, which generally question those representations of the European/Western tradition of thought and politics that only focus on their positive aspects, but differ greatly with regard to the way in which they frame and formulate their critique of this tradition. I discuss three major positions in this field. They are characterized by the rejection of Western modernity (Walter Mignolo), by a deconstruction of core text and principles of the European Enlightenment (Gayatri Spivak), and by attempts at a renewal and hence a radicalization of some of its core normative claims, particularly humanism (Achille Mbembe).
\end{abstract}

Keywords: postcolonial theories; decolonial theories; deconstruction; humanism; Enlightenment.

DOI: http://dx.doi.org/10.11606/issn.2318-9800.v23i2p35-52

This paper deals with the way in which European modernity, and the West more generally, are reflected upon within the heterogenous field of post- and decolonial theories. Post- and decolonial theorists share the conviction that European colonialism is a modern phenomenon - despite its clear diversion from some of the core (universal) principles of Western modernity. Furthermore, they hold that European colonialism and Western imperialism have done - and still do - serious damage: to a very large number of people, to culture as well as to social and political institutions in those areas of the world in which European colonialism and Western imperialism have taken and are taking action; but also to the integrity, credibility and thus the

\footnotetext{
* Ina Kerner is a professor of politics in the Department of Cultural Studies at University of KoblenzLandau, Campus Koblenz, in Germany. Her work bridges political theory, gender studies and postcolonial studies. Among her publications in English are: "Postcolonial Theories as Global Critical Theories". Constellations, 25(4), 2018, pp. 614-628; "Beyond Eurocentrism: Trajectories Towards a Renewed Political and Social Theory". Philosophy and Social Criticism, 44(5), 2018, pp. 550-570; "Solidarity across Difference Lines". Social Politics, 25(1), 2018, pp. 44-49; "Relations of Difference: Power and Inequality in Intersectional and Postcolonial Feminist Theories". Current Sociology, 65(6), 2017, pp. 846-866; and "Transnational Governmentality and Civil Society: Ambivalences of Power in a Globalized World". In: Gabriel Ricci (ed.). The Persistence of Critical Theory. Culture \& Civilization Vol. 8. New Brunswick: Transaction Publishers, 2017, pp. 85-102. In Portuguese, she published "Tudo é interseccional? Sobre a relação entre racismo e sexismo". Novos Estudos, 93, 2012, pp. 45-58.
} 
perception and reputation of European and Western knowledge systems, including their universalism. Against this backdrop, post- and decolonial theorists decidedly question those representations of the European or Western tradition of thought and politics that only focus on their positive aspects. Nevertheless, post- and decolonial theorists differ greatly with regard to the way in which they frame and formulate their critique of this tradition, as well as to the consequences they draw from their respective critiques. ${ }^{1}$

In the following, I will present and discuss what I see as three different positions in this regard. These positions are characterized by the rejection of Western modernity, by the suggestion to delink from it and to embrace both non-Western cosmologies and theoretical projects that reflect on the power effects of European colonialism and Western imperialism (Walter Mignolo); by a deconstruction of core text and principles of the European enlightenment (Gayatri Spivak); and by attempts at a renewal and hence a radicalization of some of its core normative claims, particularly humanism (Achille Mbembe). Apart from showing that post- and decolonial theories differ considerably with regard to the respective ways in which they conceptualize Western modernity, I will argue that while Walter Mignolo's decolonial position might at first sight appear as the most radical of all (and is currently perhaps the most popular of them), at a closer look the potentials for positive change that it entails and puts forward seem decidedly more limited than those of authors writing in the postcolonial theory tradition, namely Spivak and Mbembe - at least when looked upon from a Western position, or with an attention to possibilities for change in places like Europe. There will be three parts, one on each position, followed by a brief conclusion.

\section{Rejection}

Walter Mignolo is without a doubt one of the most prominent authors in the field of decolonial thought. Like others in this field, he heavily draws on the work of Peruvian sociologist Aníbal Quijano, who in the 1980s began to reorient the theoretical tradition he was coming from, namely dependency theory, by decentering its former economistic focus. Quijano claims two important things. First, that global capitalism was started in the colonial Americas; and second, that from the beginning of European colonialism on these continents, class, ethnic and racial relations were closely entangled. Right from its beginning, European colonialism established a

1 For general overviews of postcolonial theories, see, among numerous others, the classical reader by Ashcroft, Griffin and Tiffin (1995) as well as Loomba (2005); with a focus on social theory Bhambra (2014) and Go (2016); with a focus on politics and political theory Persram (2007), Seth (2013) and Kerner (2012). For an overview of the growing field of decolonial theories, see, among others, Moraña et al. (2008). 
naturalized difference classification system to support its power structure, or, in other words, to organize and rationalize the striking political inequality as well as the division of labor (including slavery) upon which it was based. The naturalized differences that this classification system produced were racial, ethnic, and national differences; and Quijano holds that both these differences as well as forms of power and social stratification they made possible, live on: both within Latin American countries and on the global scale (Quijano, 2007). To put a name to this constellation in which contemporary forms of political and social power are tainted by colonial modes of thought and organization, he has coined the notion of the "coloniality of power" (Quijano, 2000, p.171).

Walter Mignolo employs Quijano's notion of the coloniality of power to argue that this coloniality is intricately linked to modernity; he holds that modernity cannot be understood without taking its underside of coloniality into account. For Mignolo, coloniality denotes "the logical structure of colonial domination underlying the Spanish, Dutch, British, and US control of the Atlantic economy and politics, and from there the control and management of almost the entire planet" (Mignolo, 2005, p.7). So compared to Quijano, Mignolo deliberately broadens the connotation of coloniality. While Quijano when reasoning about the coloniality of power is interested in tracing current after-effects of colonialism, particularly of the colonization of the Americas, Mignolo generalizes the concept to name the logic of modern imperial power per se:

In each of the particular imperial periods of colonialism - whether led by Spain (mainly in the sixteenth and seventeenth centuries) or by England (from the nineteenth century to World War II) or by the US (from the early twentieth century until now) the same logic was maintained; only power changed hands (idem, ibidem). ${ }^{2}$

According to him - again drawing heavily on Quijano -, the coloniality of modern imperial power embraces five aspects or realms: the economic (the appropriation and privatization of land, the exploitation of labor and the control of finance); the

2 This non-differentiation of imperial logics across time and space is contested among historians of colonialism and imperialism. Latin Americanist Greg Grandin, for instance, differing from Mignolo, claims a difference between European colonialism that attempted to create great empires on the one hand, and what he calls a "new" U.S. imperialism that proclaims to spread freedom and democracy and aspires to a broad global coalition of likeminded sovereign states (Grandin, 2007). But Mignolo often over-emphasizes his contentions - and perhaps it is more fruitful to read his idea of the logic of the coloniality of power with an attention to what it is that he wants his readers to see and to acknowledge, namely this usually overlooked logic, than with an attention to the empirical contestability of some of its elements. In any case it is noteworthy that in his most recent book, Mignolo stresses - in an almost formulaic manner - the "constitution, transformation, and management of CMP," CMP standing for the colonial matrix of power (Mignolo and Walsh, 2018, p. 151, emphasis IK). But again, these transformations for the most part seem like adaptations of the same logic to changing times. "Coloniality of knowledge remained in place," he writes, "although transformed in their content and regulation" (idem, 124). An example is the shift from theological thought in the renaissance to secular thought in the enlightenment (idem, 177). 
political, or the control of authority, which refers to the realms of both the state and the military; the civic, or, to be more precise, the spread of Christian family values with their particular notions of norms of gender and sexuality); the epistemic and subjective, or the control of knowledge and subjectivity, which regarding content includes both Christian and modern rational thought, and structurally means the devaluation of non-Western cosmologies and epistemologies; as well as the control of nature and of natural resources (Mignolo, 2005, p. 11; Mignolo, 2012, p. 143). Given this list, the coloniality of power appears as a highly extensive logic.

Mignolo holds that such coloniality should be seen as "the untold and unrecognized historical counterpart of modernity" which can neither be disconnected from it nor undone otherwise, at least as long as Western modernity exists (Mignolo, 2005, p. xi). Against this backdrop, he speaks of modernity/coloniality instead of modernity, and considers all attempts at "repairing" modernity, for instance of finishing, or completing it in order to include all those who at some point in history, despite modernity's universalistic claims, have been excluded from it, as an inevitably futile endeavor that in fact could not but "keep on producing coloniality" (idem, pp. $x i, x v)$. Mignolo contests the assumption that modernity's inherent problems were problems of unequal inclusion into a framework that in principal could be assessed as both good and all-encompassing, and thus of an inadequate actualization of modernity's universalistic claims. And he seems to have two reasons for this. The first reason is the systemic inequality across all social fields that Western colonialism has produced - instead of merely not challenged and attempted to undo - from modernity's beginning. The second reason is his taking issue with the universal pretensions of Western modern knowledge and normativity claims, pretensions that to him necessarily imply the de-valuation of non-modern, or rather non-Western epistemologies and moralities. To Mignolo, Western universality necessarily implies a claim to uniformity and hence an anti-plural stance. I will come back to this below.

\section{Border thinking}

As the primary source of critique against modernity/coloniality, Mignolo suggests what, borrowing from Chicana feminist Gloria Anzaldúa (Anzaldúa, 1987), he refers to as "border thinking". To him, border thinking is a form of knowledge that critically reflects on what he calls the colonial wound, the damaging effects of colonialism and colonial modernity. This type of critical thinking necessarily entails two things: first, both subaltern and non-Western/indigenous epistemologies; and second, interculturality in the sense of epistemic plurality, which is supposed to counteract the encompassing and hence - to Mignolo - inevitably totalizing logics of modern thought. Border thinking for him is in this sense also the starting point for 
a disruption of discursive forms of coloniality or Western modernity by imagining a different, pluralized world - a world of pluriversality instead of universality (Mignolo, 2011a, p.71). Mignolo's prime example for the setting into work of interculturality are projects of bilingual education, for instance the Universidad Intercultural de las Nacionalidades y Pueblos Indígenas Amawtay Wasi, an institution of higher education in Ecuador that is closely linked to indigenous movements and in its teaching combines Spanish and Quechua knowledge systems (Mignolo, 2005, pp.117-128); as well as the thought of the Mexican Zapatistas that links Marxist categories to indigenous cosmology (Mignolo 2000, p.140). To the Zapatistas' Subcomandante Marcos, Mignolo also attributes acts and a stance of "double translation." Marcos to him is a double translator in the sense that on the one hand, he has translated local discourses from Chiapas to the Mexican nation and the global arena; and on the other hand he has translated Marxism to the local population, in a way that Marxist thought could be "infected by Indigenous cosmology" (Mignolo 2011a, p.219). According to Mignolo, Marcos has thereby "displaced the model implanted by missionaries at the beginning of the colonial world" (idem, ibidem). For him, the Zapatistas put an act of "conceptual delinking from a master frame of reference situated in Western ways of thinking" into practice (idem, 215).

\section{Delinking}

The idea of delinking is at the center of much of Mignolo's more recent texts on Western modernity. Its range of meaning encompasses different aspects and spheres. First of all, it means "epistemic disobedience", not accepting the available options, like when the non-alignment movement of the 1950s chose to delink from the major Western macro-narratives, namely capitalism and communism (Mignolo, 2011b, p. 1). In a more subject-related sense delinking furthermore means decolonization as the opposite of assimilation. Mignolo speaks of acts of undoing the coloniality of one's being, sensing and knowing, and hence one's colonial subjectivation in this regard and qualifies this type of work on the self as the first step towards pluriversal instead of universal and thus (to him) necessarily uniform horizons (Mignolo, 2012, p. 189).

As far as content is concerned, to Mignolo, delinking means a turn towards the communal, for instance in the form of the Caracoles, the local organizational units of the Zapatistas (Mignolo, 2011a, pp. 320, 324-328). Furthermore, he associates delinking with practices and conceptions of economy, politics, ethics, philosophy, technology and society that are not motivated by progress and economic growth, but rather by human well-being (Mignolo, 2012, p. 81). According to Mignolo, delinking leaves modernity/coloniality behind in so far as it parts with its predominant features, namely what he calls an "egological" epistemology and politics, to which 
he attributes universal pretentions (idem, p. 81). He holds that in practice such egological epistemology and politics translate into neoliberalism, as well as - in the words of Vandana Shiva whom he quotes at this point - into a "monoculture of the mind," a monoculture of thinking (idem, p. 67). The effect of this monoculture is a suppression and displacement of other, particularly of non-individualist and of non-rationalist forms of sensing and thinking. And it is precisely such subjugated epistemologies that delinking attempts to make space for (idem, p.170). The aim of this space-making gesture is not to replace Western universalism with any kind of non-Western epistemology or doctrine. Rather, the aim is to foster epistemic plurality. And in this sense, delinking for Mignolo does not mean to position oneself simply outside of capitalism and Western civilization. Rather, it means embracing "exteriority", the position of "the outside created in the process of creating the inside" (Mignolo, 2011b, p.6), which can be understood as the position of those who have been excluded, made superfluous, rendered as the other in processes of Western self-formation.

In his 2011 book The Darker Side of Western Modernity Mignolo presents delinking as the "decolonial option" (Mignolo, 2011a). This is his preferred future trajectory out of a list of five such trajectories; next to the decolonial option these are "rewesternization", for instance in the foreign politics of the Obama administration that attempted at rebuilding global confidence in the U.S, "reorientations of the Left", ranging from the World Social Forum and Chavismo all the way up to organizations like Hamas and Hezbollah, "dewesternization” or Asian self-affirmations against Western thought, particularly in current India and China, and the "spiritual option" that seeks to find ways beyond consumer capitalism and development, like in the case of Native American conceptions of land as spiritual rather than as a commodity, and of buen vivir, the good life, as different from development (idem, p. 35-63). In short, the decolonial option means epistemic disobedience, acts of delinking from modernity/ coloniality and the colonial matrix of power in favor of embracing alternative routes which, both individually as well as taken together, establish a "pluriversal world, a world in which truth and objectivity in parenthesis is sovereign" (idem, p. 52).

\section{Pluriversality}

Mignolo is highly critical of what he calls "objectivity without parentheses" (Mignolo, 2011a, p.90), which he holds to result in what we might want to call populism or totalitarianism on the one hand, and exploitative forms of capitalism on the other hand; in his own words, "a closed political system ready to be taken by totalitarian regimes and fertile for an economy in which increases of production and wealth take priority over human lives and life in general" (idem, p. 70). Nevertheless, 
it remains unclear what exactly he refers to when he speaks of "objectivity without parenthesis" and of what seems to be its synonym, universality - for instance when he notes that the "desirable hegemony is the hegemony of truth in parenthesis that defines the horizon of pluriversality as a universal project" (idem, p. 44). Mignolo clearly states that pluriversality was different from cultural relativism (Mignolo, 2012, p. 199). Nevertheless, the hegemony of truth in parenthesis he envisions seems to be a pluralism of independent epistemic communities that refrain from imposing their perception of truth on others; and these communities seem to be more or less self-reliant units that are based on a shared, and hence internally noncontroversial, world-view, instead of highly interlinked, fluid entities with multiple forms of exchange and dialogue. So it remains unclear in which way pluriversality cannot not lead to cultural relativism.

Western epistemology, by contrast, in Mignolo appears as a homogenous black box, a box in which everything works according to the same logic of rationality and universalism. To me, this conception seems questionable - for two reasons. First, it neither acknowledges those currents within Western thought that conceptualize modernity as dialectic or ambivalent - like for instance first generation Frankfurt School critical theory or poststructuralism - nor those currents within Western thought that precisely criticize any favoring of individualism and individualist rationalism; examples for the latter range from feminist care ethics (e.g. Gilligan, 1982; Larrabee, 1993) via positions in the field of post-humanism (e.g. Braidotti, 2013; Haraway, 2016) to the convivialist manifesto (Les Convivialistes, 2014). ${ }^{3}$

Second, I hold that several serious problems of Western modernity's history and present, like colonial racism or different kinds of gender hierarchies, while they probably should be described as being linked to colonial modernity, are not effects of normative universalism as a concept, but rather of the construction of those naturalized differences that Quijano talks about, and therefore of the reduction of universal justice claims to a lucky few, namely white European heterosexual males, and the exclusion from these claims of all others. Mignolo is neither interested in teasing out the potential gaps between normative universalism and Western epistemic imperialism (with necessarily totalizing effects), nor in the rift between Western modern universalism and Western modern difference claims. ${ }^{4}$ Rather, he contents himself with qualifying all of these strands of thought as aspects of the colonial

\footnotetext{
3 It must be noted that in his latest book, Mignolo does briefly refer to Rosi Braidotti's book on the posthuman. But he jumps to opposing her position to the work of decolonial critiques of Western notions of the human, and to qualify her take on the posthuman as "a Eurocentric critique of European humanism" (Mignolo and Walsh, 2018, pp. 171). He does so regardless of the fact that in her book that he refers to, Braidotti affirms the postcolonial and ecofeminist critique of humanism by authors like Frantz Fanon, Edward Said, Paul Gilroy and Vandana Shiva (Braidotti, 2013, pp. 4550) - authors whom Mignolo usually reclaims for his own theoretical position, as well.

4 For a more detailed critique of this disinterest, see Kerner (2017).
} 
Ina Kerner

matrix of power.

\section{Deconstruction}

Gayatri Chakravorty Spivak interrogates Western modernity in a decidedly different way than Mignolo. Like him, she is far from reducing Western modernity to its noble ideas and ideals. Unlike him, however, she neither treats it as a black box nor fully rejects it. Rather, she engages in complex deconstructive readings of Occidental claims, texts and action. While Mignolo rejects modernity/coloniality, which he holds to be a fixed package, Spivak considers enlightenment thought as valuable, and any wholesale rejection of it as dangerous. Accordingly, she assesses the globalization of European enlightenment thought through European colonialism as both an enablement and a violation, and claims a double-edged attitude to it (Spivak, 2008, p. 263f., FN 2). In her book A Critique of Postcolonial Reason she has coined the expression "enabling violation" to have a name for the ambivalence that is prevalent here (Spivak, 1999, p. 371); but it is important to note that to her, this ambivalence can never serve as an excuse, or even ennoble, the violating component of the colonial globalization of European enlightenment thought. As an explanation she offers the image of "a rape that produces a healthy child, whose existence cannot be advanced as a justification for the rape" (idem, ibidem). "Imperialism cannot be justified by the fact that India has railways and I speak English well", she adds (idem, ibidem). But this does not render any aspect that imperialism globalized either useless or problematic. On the contrary: "the enablement must be used even as the violation is re-negotiated" (Spivak, 2008, p. 15), Spivak claims.

\section{Deconstruction as method}

Spivak has become famous in the realm of U.S. humanities as the translator of Jacques Derrida's book Of Grammatology. Accordingly, to her, a "deconstructive politics of reading" would refrain from any rejection of the great enlightenment authors like Kant, Hegel or Marx as "motivated imperialists" - not the least because she holds "our sense of critique" to be "too thoroughly determined" by those authors (Spivak, 1999, p. 6f.). Instead, deconstruction would attempt to put their thought to use, or, in her own words, it would "acknowledge the determination as well as the imperialism and see if the magisterial texts can now be our servants" (idem, p. 7). Against this backdrop, Spivak's plea for using the enablement that European enlightenment comes with is a deconstructive move par excellence.

But to her, deconstruction entails even more. It also implies "displacing rather than only reversing oppositions (such as between colonizer and colonized) by taking 
the investigator's own complicity into account" (idem, p. 244) - which does not only mean a move beyond colonial difference lines, but also a self-reflexive stance. Three aspects seem important in this regard.

First, a self-reflexive and hence self-critical mode which necessarily also includes the critic and her critique itself. Second, a stance of providing constant critical accompaniment to something one has not founded nor aspires to found, but rather finds oneself confronted with, something one may assess as problematic, yet that "one cannot not want" (Spivak, 1996, p. 28). The third aspect, finally, is the production of readings and interpretations that complicate common assessments of things, and hence also of Occidental claims and action, and that shift their (historical) complexities into focus.

Regarding the first item on this list, the self-reflexive mode, Spivak elaborates on various aspects. First of all, she problematizes the romanticizing of precolonial conditions and cultures. Furthermore, she is highly critical of romanticizing the subaltern, their knowledge and their readiness for political resistance in the present, and holds that such representations of the subaltern often serve to render romanticizing authors' own political aspirations, as well as their authorship in the act of representation, transparent - a concern that she has written about in greater detail in her essay "Can the Subaltern Speak?" with regard to Michel Foucault and Gilles Deleuze (Spivak, 1988). Another, less romanticizing non-reflexive example of representation she discusses critically is Edward Thompson's 1920s book Suttee: A Historical and Philosophical Enquiry into the Hindu Rite of Widow-Burning, that according to her, due to its methodological Eurocentrism, evokes the problematic figuration of " 'the third-world woman' caught between tradition and modernization, culturalism and development" (Spivak, 1999, p.304), a figuration that occludes actual Indian women. "Nowhere in his book, written by someone who avowedly 'loved India,' is there any questioning of the 'beneficial ruthlessness' of the British in India as motivated by territorial expansionism or management of industrial capital" (idem, p. 303), she writes. To her, the problem of this book is therefore a problem of representation: "The construction of a continuous and homogenous 'India' in terms of heads of state and British administrators, from the perspective of a "man of good sense' who would be the transparent voice of reasonable humanity" (idem, ibidem). So here, too, the investigator's complicity is concealed.

But Spivak, who is keen on displacing (rather than simply reversing) oppositions, does not extend her critique with regard to sati to the British in India alone. She is similarly critical with regard to male local elites, some of whom collaborated with the British in codifying Hindu law (and hence also the once decidedly more complex regulations with regard to sati), and others of whom romanticized this practice. According to Spivak, instead of misrepresenting sati as a widespread misogynist 
tradition, as the British did, local elites misrepresented it as an expression of the free will of true Indian women: "The ambiguity of the position of the indigenous colonial elite is disclosed in the nationalistic romanticization of the purity, strength, and love of these self-sacrificing women" (Spivak, 1999, p.296), she writes.

It seems to be both her deconstructivism and her feminism that make Spivak go beyond colonial oppositions - in favor of assessing colonial and postcolonial constellations in a more nuanced way, in fact in a way that attempts at shifting (historical) complexities into focus, particularly where they have been occluded. ${ }^{5}$ With regard to how history is narrated, this implies an interest in, and an attention to, the ruptures colonialism has produced, as well as the legacy of these ruptures after independence. "One of the most fascinating aspects of postcoloniality in a former colony is the palimpsest of precolonial and postcolonial continuity raptured by the imperfect imposition of the Enlightenment episteme, itself travestied in the metropolitan social formations of the eighteenth and nineteenth centuries", Spivak writes (Spivak, 1999, p. 239f.). To illustrate how this should be understood she refers to the hill district of Sirmur in Northern India, now part of India's parliamentary democracy, which under British rule was recognized as a princely state. According to Spivak, the royal house of Sirmur "had come to feel its 'royal'-ness rather more strongly under colonial influence, writing its accoutrements on a European model, or even perhaps a European conception of a 'native' king” (idem, p. 240). So in this example, colonialism did not at all mean a doing away with feudal traditions - it rather reinforced these traditions. The enlightenment that Europe exported was at best an imperfect one.

\section{Human rights in practice}

In 2004, Spivak published an essay on the question of human rights called "Righting Wrongs". This essay is another illustration of Spivak's double-edged critical attitude to Western modernity; furthermore, it is an example of what she means when she suggests using the enablements of European enlightenment.

To set out, Spivak clarifies that she is not at all interested in problematizing human rights as inherently Eurocentric, as other critics might do; rather, she thinks of how their potentials may be put to use for the task of "the righting of wrongs" (Spivak, 2008, p. 15). According to her, this practice indeed blurs the European origins

\footnotetext{
5 Spivak's critique of colonial oppositions also includes race thinking, or "chromatism", as she calls it (Spivak, 1999, p. 164). To her, any reproduction of such thinking, including in the realm of anti-racist feminism relying on the category of "women of color", is highly problematic - since it "belongs to the repertory of colonialist axiomatics" and furthermore "is based on the implicit acceptance of 'white' as 'transparent' or 'no-color,' and is therefore reactive upon the self-representation of the white” (idem, pp. 167, 165).
} 
of human rights, or rather renders them politically irrelevant: "in the Global South, the domestic human rights workers are, by and large, the descendants of the colonial subjects, often culturally positioned against Eurocentrism" (idem, p. 16), she writes. So we can say that for Spivak, the practice of righting wrongs is what matters most with regard to human rights; that human rights interest her less as a legal text, but rather as a political instrument to be used from below; and that the human rights text in fact becomes valuable precisely when it is used from below, and in this sense accompanied by activism.

Spivak's concrete suggestion with regard to the critical accompaniment of the legal text of human rights by political action from below is to engage in educative work, in a particular kind of pedagogy. The basic aim of such work is an empowerment of the subalterns (particularly the rural poor in the Global South), an empowerment that makes it possible for them to learn about their entitlements, and that enables them to perceive themselves as subjects of human rights in the first place. The educational efforts that Spivak envisions and explains in her essay (after for several years she undertook them herself) basically consist in teacher's trainings in the poor parts of the Indian countryside - trainings which on a very practical level work against the predominant pedagogy that merely consists in making students memorize instead of comprehend any content, and which furthermore foster students' democratic reflexes of questioning authorities. Spivak hopes that in the long run, this may foster the activation of democratic structures; structures in which human dignity is understood in the sense of an enjoyment of rights (Spivak, 2008, p. 49ff.). "[I]t is in view of Marx' hope to transform the subaltern [...] into an agent of the undoing of class apartheid rather than its victim that this effort at educating the educator is undertaken" (idem, p. 28), Spivak claims. Class apartheid in education to her is the difference between rote and comprehension - rote learning for the poor, education fostering comprehension for the middle and upper classes (idem, p. 53f.). Spivak characterizes the Indian public sector education system as "a corrupt ruin of the colonial model" (idem, p. 56). An education that "teaches the habit of democratic civility" and enables students to perceive themselves as subjects of universal human rights and to act accordingly (idem, ibidem), is hence an act of using select aspects of the European enlightenment tradition against legacies of European colonialism. It is the use of the enablement to undo the long-term effects of the violation.

\section{Renewal}

To briefly repeat: Mignolo rejects Western modernity as always already colonial and suggests acts of delinking in favor of what he calls the decolonial option, namely critical border thinking and ways of thought and life that draw on knowledge that has 
been subjugated and exteriorized by European colonialism and Western modernity. Spivak, by contrast, engages in critical reflections of modern texts, ideas and action in order to deconstruct them, to shed light on their contradictions and ambivalences, their instrumentalization, their unfulfilled promises, their silences and their power effects - but also on their potentials as tools towards more justice. She does so precisely because she assumes that we cannot want to do without these texts and ideas. But she also holds that we should not only try to stay clear from reproducing their problems, but to furthermore undergo the extra effort that is needed for the task of actually putting them to emancipatory use. And the "we" in this sentence refers to everyone, but maybe particularly to those of us who do not find themselves in a subaltern position, yet aim towards a better, a less unjust world for all.

Achille Mbembe chooses a third path, a path that partly coincides with the one pursued by Spivak, and partly leads further, or at least in a slightly different direction: the path of renewing select concepts, norms and ideas that the Western legacy provides us with. Since his work focuses to a great extent on the history, mechanisms and legacy of colonial racism with its long tradition of de-humanizing black Africans as well as their descendants, it is not coincidental that the concept that he aspires to renew is the one of humanism. Mbembe develops his ideas regarding this renewal with reference to the work of Frantz Fanon - particularly to Fanon's plea for a new, critical humanism and to his conviction that a better world requires the destruction of colonial divisions and patterns of compartmentalization (Fanon, 2004). What against this backdrop Mbembe calls for is the formation of ethical communities that transcend colonial lines of differentiation, and thereby have the potential to finally undo them. ${ }^{6}$

\section{The legacy of colonial racism}

In several of his writings, Mbembe reaches this suggestion after walking his readers through detailed, and often painful, accounts of colonial racism and its afterlife. Already in his seminal work On the Postcolony (Mbembe, 2001) he focuses on the epistemic, or discursive dimension of colonial practices and their effects in colonies and postcolonies - primarily those racist difference constructions that European colonial powers used to render Africa as Europe's Other and that negated its peoples the status of full humanity. Mbembe characterizes such difference constructions as a form of power inherently connected to violence. Part of this refers to their content: according to him, the reduction to physicality, ascriptions of irrationality and the animalization and bestialization that characterized colonial

6 For a discussion of the differences between Mbembe's and Mignolo's interpretations of Fanon, see Kerner (2014); for further interpretations of Fanon's humanism see Gilroy (2011) and Go (2012). 
imaginations of the African population had brutalizing effects (idem, p. 14). Furthermore, such images of Africans did not only circulate in the sphere of the cultural, but were institutionalized in the course of the slave trade and colonialism; they were materialized in various ways. According to Mbembe, this made violence infuse economy, the private, language and consciousness; it became a cultural practice and constituted a spirit of violence with far reaching subjectivation effects (idem, p. 175). In his more recent book Critique of Black Reason (Mbembe, 2017), Mbembe focuses on the brutality and the dehumanizing effects of colonial racism once more - this time broadening his geographical focus to include Europe and North America in terms of such effects. He does not only give a detailed account of European race thinking as well as of its re-actualizations in fields as diverse as genomics, reproductive technologies, and the spheres of digitization, securitization and surveillance; also capital, he claims, "still leverages racial subsidies in its pursuit of profit", particularly in its ongoing acts of primitive accumulation (idem, p. 23). Even more so than for the present, it is for modern European history as well as for world history that Mbembe claims intricate links between colonialism and capitalism - with the plantation in the Americas, based on black slave labor, as its most strident manifestation. Furthermore, he stresses that colonial political practice was based on a coupling of habitualized race logics, the logic of profit, a politics of violence and an instinct for corruption (idem, p. 62). It is important to note that according to Mbembe, the maintenance of this constellation required a pedagogy of habituation to racism in the metropoles; such a pedagogy was "founded essentially on the principle that the relationship to Blacks must be a relationship of nonreciprocity" (idem, p. 63). Accordingly, to Mbembe, the legacy of European modernity can only be understood in correlation to European race history: "the coming of modernity coincided with the appearance of the principle of race and the latter's slow transformation into the privileged matrix for techniques of domination, yesterday as today" (idem, p. 55), he stresses. And it almost goes without saying that to him, a meaningful critique of European modernity must therefore necessarily be a critique of all forms of European racism, as well.

\section{The idea of a common human nature}

It is precisely against this backdrop of the pervasiveness of colonial racism in the history of our global present that Mbembe suggests the strengthening of the idea of a common human nature, an idea that for a long time posed - and maybe still poses - "a problem for Western consciousness" (Mbembe, 2001, p. 2). It is important to note that the strengthening of the idea of a common human nature, as Mbembe suggests it, implies both sides of the former colonial split. With regard to the colonized, 
Mbembe argues that Fanon's revolutionary theory should be interpreted within the context of a more general theory of the rise in humanity, when he writes:

The colonized has to propel himself, by his own force, to a level above the one to which he has been consigned as a result of racism and subjugation. [...] In this way, he restores the possibility, for him personally and for humanity as a whole, starting with his executioners, of new and open dialogue between two equal human subjects where, previously, there had been opposition between a man (the colonialist) and his object (the colonized). From then on there is no more black and white. There is only a world finally rid of the burden of race, a world to which everyone has a right (Mbembe, 2012, p. 24).

As this quote should make clear, when Mbembe speaks of a common human nature or the rise in humanity, he does not refer to Western humanism and universalism in an unbroken way. Neither does he endorse some simple form of postracialism, announced from above. For like Mignolo, he holds that there is a racist underside that the Western tradition of thought has produced in order to be able to restrict its assertive claims to people of European descent (Mbembe, 2009, p. 34). Unlike Mignolo, however, Mbembe claims that it is possible to move away from this constellation. What to him is needed for not reproducing the effects of the colonial order in the present is a political culture that makes it possible for every person to regain subject status, to be recognized as a fellow human and to engage in person-to-person dialogue, also across the former difference lines. Creating the preconditions and hence the possibilities for such a political culture is the task that Mbembe assigns to former colonial states: through acts of an adequate politics of memory that publicly acknowledges, and takes responsibility, for the atrocities of European colonialism and the harm that it caused; by acts of restitution, particularly of human remains, the establishment of memorial sites and museums; and, even more important, by forms of material compensation and reparations. Such forms of compensation to Mbembe serve to undo some of the long-term effects of centuries of colonial exploitation; but they also have the symbolic effect of re-entering into a relation of reciprocity and mutuality (Mbembe, 2010, p. 52f.; Mbembe, 2017, p. 182f.). Only such a culture of mutuality and the common would enable the disruption of violent colonial hierarchies, on the one hand, and anti-colonial counter violence and revenge on the other (Mbembe, 2009, p. 35).

\section{Transgressing colonial difference lines}

So while for Mignolo, who advocates acts of delinking, hopes for a better future are restricted to contexts that are posited outside of modern/colonial logics, Mbembe's aim is to establish ethical communities precisely across former colonial difference lines - as difficult as this might be. In South Africa, for example, according 
to him it demands no less than a recognition of "black people's capacity for selfmaking, self-reference and self-expression" and "versions of whiteness that are [...] constituted [...] around an ethics of mutuality and human solidarity" (idem, p. 36) and hence a severe break with logics and mindsets of apartheid.

Furthermore, I'd like to argue that while Mignolo renounces the European tradition, and while Spivak is interested in attempts at putting its enabling tools to emancipatory use, Mbembe holds that tradition, and those who claim to be its trustees, accountable. According to him, postcolonial thought "calls upon Europe to live what it declares to be its origins, its future and its promise, and to live all of that responsibly" (idem, p. 38). For how a good model of conviviality across former, colonial difference lines may look like, Mbembe refers to what he calls "Afropolitanism" - and hence precisely not to European examples, but to African ones. To him, Afropolitanism is on the one hand a form of thought that rather looks for transgression than for roots; on the one hand it is the lived experience of people in African countries, shaped by migration, dispersion and mobility, and a form of identity that rather embraces then expels the foreign and the strange, that in fact counts with the foreign and the strange as a normal condition of life (Mbembe, 2010, p. 221-229). That (not only) contemporary Europe has a lot to learn from such a stance, is without any doubt.

\section{Conclusion}

Mignolo, Spivak and Mbembe differ in many respects - but in some regards their critical accounts of Western modernity also overlap, or at least seem compatible. All three stress that European colonialism wasn't in the first place a strategy-game of European states that competed for their place in the sun (which is what until today you often learn in school in Germany, for example), nor a noble civilizing mission - but rather a severe violation, comprising genocide, slavery, massive forms of dispossession and exploitation, social, political and cultural destruction, and the global institutionalization of racism, including the sub-categorization of humanity into different naturalized as well as hierarchized "races". Mignolo, Spivak and Mbembe also stress that European colonialism has always been intricately linked with, has always been a component of, Western modernity, and that from a colonial (and, for that matter, post- and decolonial) perspective, this has always been quite apparent. I hold this to be very important - since from a Western European perspective, this link for a very long time has not been apparent, has in fact been systematically occluded, which I think should be interpreted as an effect of coloniality itself. This occlusion might have worked since the barbarity that was an essential part of European colonialism happened for the most part outside of the European mainland. But this 
also means that modern Europe from its beginning engaged in a huge endeavor of exporting barbarity. Mignolo, Spivak, Mbembe and several other authors writing in the critical traditions of post- and decolonial theory remind us to take this export of barbarity seriously when we attempt at understanding both Western modernity and the world as we know (and often don't know) it. And they remind us to do so because they have good reasons to assume that the effects of this export (and in parts, the export itself) are far from over.

Mignolo, Spivak and Mbembe differ with respect to the conclusions they draw from this diagnosis, though. ${ }^{7}$ Mignolo seems to be the most pessimistic, or skeptical, with regard to possibilities of repairing the modern constellation - hence his suggestion to delink from it, to exit, and to find resources for creating alternatives in Western modernities' exteriorized communities and cosmologies, as local as these may always remain. Spivak, on the other hand, rather looks out for the ambivalences of Western modernity, and seeks to make use of the enablements it promises to everyone while stressing that these enablements don't at all come natural to everyone, but rather have to be claimed and fought for. But in the sense that European colonialism globalized these enablements, she holds them to be universal (and indispensable); at least in principle. Mbembe, finally, even goes a step further, when he holds Europe accountable for what it proclaims to stand for. If taken seriously, the implications of such an attempt of Europe at assuming accountability would imply tremendous change - within the continent itself, but also globally. Border regimes and migration politics would be one among many other aspects of such change. ${ }^{8}$

\section{References:}

Anzaldúa G. (1987). Borderlands/ La Frontera: The New Mestiza. San Francisco: Aunt Lute Books.

Ashcroft B., Griffiths G. and Tiffin H. (1995). The Post-Colonial Studies Reader. London - New York: Routledge.

Bhambra G.K. (2014). Connected Sociologies. London Bloomsbury.

Braidotti R. (2013). The Posthuman. Cambridge - Malden/MA: Polity.

Fanon F. (2004). The Wretched of the Earth. New York: Grove Press.

7 At this point it must remain an open question to which extent the differences between Mignolo, Spivak and Mbembe are not "merely" theoretical, given to the different intellectual traditions they build their accounts on, but also influenced by the distinct historical trajectories and experiences they base their respective theorizing on - Mignolo from the perspective of Latin American colonial experiences, Spivak with reference to Indian ones, Mbembe mostly to (South) African ones.

8 The first, basic draft of this text was written during my stay as a fellow at Käte Hamburger Kolleg I Centre for Global Cooperation Research (KHK/GCR21) in Duisburg, Germany. I am indebted to the Centre, especially its staff and researchers, for the wonderful work atmosphere they have created. I also profited greatly from presenting and discussing a former version of this paper at the Centre's weekly colloquium, as well as at the "Philosophy and Social Science Conference" 2018 in Prague and at the 2018 American Political Science Association Annual Meeting in Boston. 
Gilligan C. (1982). In a Different Voice. Psychological Theory and Women's Development. Cambridge/MA - London: Harvard University Press.

Gilroy P. (2011). Fanon and the Value of the Human. The Johannesburg Salon, 7-14. (http://jwtc.org.za/volume_14/paul_gilroy.htm [access: November 18 ${ }^{\text {th }} 2018$ ]). - (2012). Fanon's postcolonial cosmopolitanism. European Journal of Social Theory, 16, pp.208-225.

. (2016). Postcolonial Thought and Social Theory. Oxford - New York: Oxford University Press.

Grandin G. (2007). Empire's Workshop. Latin America, the United States, and the Rise of the New Imperialism. New York: Holt.

Haraway D. (2016). Staying with the Trouble. Making Kin in the Chthulucene. Durham: Duke University Press.

Kerner I. (2012). Postkoloniale Theorien zur Einführung. Hamburg: Junius.

. (2014). "Countering the Legacies of Colonial Racism - Delinking and the Renewal of Humanism". In: Broeck S. and Junker C. (eds.). Postcoloniality - Decoloniality - Black Critique: Joints and Fissures. Frankfurt/M. - New York: Campus, pp.145-158. 50, pp. 8-11.

. (2017). Universalismus: Ansprüche, Probleme und Potentiale. $\mathrm{ARCH+}$,

Larrabee M.J. (1993). An Ethic of Care. Feminist and Interdisciplinary Perspectives. London - New York: Routledge.

Les Convivialistes (2014). Convivialist Manifesto. A declaration of interdependence (Global Dialogues 3). Duisburg: Käte Hamburger Kolleg / Centre for Global Cooperation Research (KHK/GCR21).

Loomba A. (2005). Colonialism/Postcolonialism. Second Edition. London - New York: Routledge.

Mbembe A. (2001). On the Postcolony. Berkeley - Los Angeles: University of California Press.

(2009). Postcolonial Thought Explained to the French. The Johannesburg Salon: pp. 34-39 (http://www.jwtc.org.za/the_salon/volume_31/ achille_mbembe.htm).

Paris: Découverte.

- (2010). Sortir de la Grande Nuit. Essai sur l'Afrique décolonisée. - (2012). Metamorphic Thought: The Works of Frantz Fanon. African Studies, 71, pp. 19-28.

Press.

. (2017). Critique of Black Reason. Durham - London: Duke University

Mignolo W. (2005). The Idea of Latin America. Malden - Oxford: Blackwell.

(2010). Local Histories/Global Designs. Coloniality, Subaltern Knowledges, and Border Thinking. Princeton: Princeton University Press. 
- (2011a). The Darker Side of Western Modernity. Global Futures, Decolonial Options. Durham - London: Duke University Press.

. (2011b). Geopolitics of Sensing and Knowing. On (De)Coloniality, Border Thinking, and Epistemic Disobedience. transversal (http://eipcp.net/ transversal/0112/mignolo/en/print: 1-9).

. (2012). Epistemischer Ungehorsam. Rhetorik der Moderne, Logik der Kolonialität und Grammatik der Dekolonialität. Wien - Berlin: Turia + Kant.

Mignolo W. and Walsh C. (2018). On Decoloniality. Concepts, Analytics, Praxis. Durham - London: Duke University Press.

Moraña M., Dussel E. and Jáuregui C. (2008). Colonialism and its Replicants. In: Moraña M., Dussel E. and Jáuregui C. (eds.). Coloniality at Large. Latin America and the Postcolonial Debate. Durham - London: Duke University Press, pp.1-20.

Persram N. (2007). Postcolonialism and Political Theory. Lanham - Plymouth: Lexington.

Quijano A. (2000). Coloniality of Power, Eurocentrism, and Latin America. Nepantla, 1 , pp. 533-580.

pp. 168-178.

(2007). Coloniality as Modernity/Rationality. Cultural Studies, 21,

Seth S. (2013). Postcolonial Theory and International Relations. Acritical Introduction. London - New York: Routledge.

Spivak G.C. (1988). Can the Subaltern Speak? In: Nelson C. and Grossberg L. (eds.). Marxism and the Interpretation of Culture. Urbana - Chicago: University of Illinois Press, pp.272-313.

- (1996). Bonding in Difference. Interview with Alfred Artega. In: Landry D. and MacLean G. (eds.). The Spivak Reader. London - New York: Routledge, pp.15-28.

- (1999). A Critique of Postcolonial Reason. Toward a History of the Vanishing Present. Cambridge, Mass - London: Harvard University Press.

. (2008). Other Asias. Malden - Oxford: Blackwell.

Esta obra está licenciada com uma Licença Creative Commons Atribuição-NãoComercial-

-Compartilhalgual 4.0 Internacional.

https://creativecommons.org/licenses/by-nc-sa/4.0/

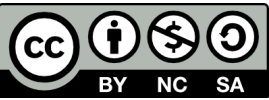

